\title{
Antimicrobial Activity of Fungal Extract of The Aspergillus flavus from Hiri Island, North Maluku to Pathogenic Bacteria
}

\author{
Sri Sedjati 1,2,4 *, Ambariyanto Ambariyanto 2,3, Agus Trianto 2,3, Endang Supriyantini2, \\ Ali Ridlo², Muhammad S. Bahry3, Rizky R. Jezzi², and Mahadika F. Sany² \\ 'Doctor Program of Marine Science, Faculty of Fisheries and Marine Science, Diponegoro University \\ ${ }^{2}$ Marine Science Department, Faculty of Fisheries and Marine Science, Diponegoro University \\ 3 Integrated Laboratory, Diponegoro University \\ Jl. Prof. Soedarto, Tembalang, Semarang, Jawa Tengah 50275, Indonesia \\ ${ }^{4}$ Marine Science Techno Park \\ JI. Undip, Desa Teluk Awur, Tahunan, Jepara, Jawa Tengah 59427 Indonesia \\ Email: sedjati69@gmail.com
}

\begin{abstract}
Antibacterial compounds from sponge association fungi are one of the alternatives to search for new antibiotics against resistant bacteria. This study aims to explore the secondary metabolites potential from sponge association fungi as MDR pathogens antibacterial and to cultivate these fungi using a variety of cultivation media. TE-BO-09.1. Isolate can inhibit 3 bacteria, K. pneumoniae, $B$ subtilis, and S. aureus, but is not able to inhibit E. coli and P. aeruginosa. Cultivation using standard media of Malt Extract Agar (MEA) and media modified from fish broth (M1, M2) and cassava infusion (M3, M4) produce secondary metabolites with varying quantities and antimicrobial activity. The inhibition zone of the produced extract with $500 \mu \mathrm{g} /$ disc concentration ranged from 7.14 to $10.32 \mathrm{~mm}$. The strongest potential was shown by ethyl acetate extract from isolates cultured with M2 (9 days cultivation), of which is able to produce $10.32 \mathrm{~mm}$ inhibition zones against $\mathrm{S}$. aureus and methanol extracts from isolates cultured with M4 (6 days cultivation), and able to produce 10.05 $\mathrm{mm}$ inhibition zones against $\mathrm{K}$. pneumoniae. In conclusion, the fungus Aspergillus flavus can be culture using fish broth added glucose and cassava infusion water added peptone media to potentially produce antibacterial compounds against MDR pathogens.
\end{abstract}

Keywords : secondary metabolites; antibacterial; association fungi; MDR pathogens

\section{INTRODUCTION}

More than $70 \%$ of hospital infections are caused by bacteria that are resistant to at least 1 type of antibiotic, and some of which are even resistant to 3 or more antibiotics (multi-drug resistant/MDR) as stated by Krzowska-Firych et al., (2014). These bacteria can be found in gram-positive groups (vancomycin - resistant enterococci / VRE, methicillin-resistant Staphylococcus aureus / MRSA) and gram-negative (Klebsiella spp., Acinetobacter spp., Pseudomonas spp.). The infectious bacteria which are often identified are Enterococcus faecium, Staphylococcus aureus, Klebsiella pneumoniae, Acinetobacter baumannii,
Pseudomonas aeruginosa, and Enterobacter sPp. known as "ESKAPE pathogens". Other bacteria are also often infectious, i.e. Streptococcus spp., Acinetobacter spp., Enterococci, Negative Stagylococcus Coagulase, Bacillus cereus, Legionella spp., Proteus mirabilis, Escherichia coli, Serratia marcescens. (Bereket et al., 2012; Bologa et al., 2013; Ahmad, 2015; Almasaudi, 2015 ; Bouguenoun et al., 2016; Miao et al., 2017). Abebe et al. (2016) summarizes some molecular mechanisms which trigger bacterial resistance, they are: (a) bacterial enzymes which hydrolyze antibiotics to be inactive, (b) changing antibiotic targets (mutations of bacterial genes), (c) preventing antibiotic permeation on target 
microorganisms, (d) antibiotic extracellular secretions (e.g. by using active efflux pump), and (e) forming biofilm.

Antibiotic resistance is a public health problem faced by many countries, including Indonesia (Kemenkes RI, English term: Ministry of Health of The Republic of Indonesia, 2011). Antibiotic resistance occurs when microorganisms undergo changes that cause the drugs used to cure the infections to become ineffective. Antibiotics are well known as drugs that are used to treat bacterial infections. Antibiotics can be bactericidal (killing bacteria) or bacteriostatic (preventing bacterial proliferation) (Kemenkes Rl, 2015). Resistant microorganisms prevention can be solved by finding new antibiotics that can kill the bacteria. Moreover, one alternative source of new antibiotics is derived from natural ingredients, including from marine biological materials.

Some fungi from Indonesian waters are scientifically proven to contain antibacterial compounds. Sponge association fungus from Riung waters (East Nusa Tenggara) has the potential to produce antibacterial compounds of MDR S. aureus and E, coli (Wittriansyah, et al., 2016). Endophytic fungi from Haliclona fascigera living in Mandeh Island waters (West Sumatra) produces ethyl acetate extracts that can inhibit bacteria $S$. aureus and E. coli (Handayani et al., 2015). Plakotis melobesioide sponge association fungus from Malalayang waters (North Sulawesi) also has the potential to produce new antibacterial as well. Its methanol extract contains semi-polar bioactive compounds that can inhibit the growth of $S$. aureus bacteria better than chloramphenicol (Sihombing et al., 2017). Several other researchers have also succeeded in isolating and identifying active compounds, such as Trichoderma asperellum and T. reesei fungus from sponge Cinachyrella sp. which produce antibacterial E. coli strain MDR (Sibero et al., 2017); Aspergillus sydowii fungus from sponge Axinella $s p$. produces antibacterial $S$. aureus and E. coli MDR strains (Trianto et al., 2017) and T. saturnisporum fungus from Pandang Island waters (North Sumatra) produces antibacterial Staphylococcus enterica MDR strain (Sibero et al., 2018).
A study conducted by Zhou et al. (2016) showed that secondary metabolites of marine fungi from different habitats would produce compounds with different activities. Another factor is the difference in cultivation media as Ozkaya et al. (2018) proved that sponge association fungi which were cultivated in different media turned out to produce different secondary metabolites, both in their types and activities. The purpose of this study is to find out the potential of secondary metabolites of sponge association fungus as an antibacterial and to cultivate the fungus using various cultivation media. It is expected that relatively inexpensive media can produce metabolites with high bioactivity against pathogenic bacteria.

\section{MATERIALS AND METHODS}

The sample was isolated from a sponge obtained from western Hiri Island waters (Big O with coordinates $00^{\circ} 53^{\prime} 47.77^{\prime \prime} \mathrm{N}$ $127^{\circ} 18^{\prime} 16.61 \mathrm{E}$ ), North Maluku, Indonesia (as seen in Figure 1). The fungus isolate with code TE-BO-09.1 has been identified in previous antibacterial screening research. Molecular identification of ITS rDNA sequences showed that the fungus was identified as Aspergillus flavus (Trianto et al., 2020).

\section{Morphological Characterization of Fungus}

Active fungal isolates were cultivated using MEA media (Merck) for 7 days (at $27^{\circ} \mathrm{C}$ incubation temperature) for macroscopic observation of the colony shape. Furthermore, the microscopic characteristics were determined based on the slide culture method (Maurya et al., 2011; Sibero et al., 2017) by administering Lactophenol Blve and then were observed using a microscope with 100 times magnification.

\section{Antimicrobial Activity Screening}

Initial antibacterial screening or also called as antagonistic testing was carried out using agar plug method (Trianto et al., 2017; Sibero et al., 2018). Besides, the fungal association was cultured in MEA media for 7 days at $27^{\circ} \mathrm{C}$ temperature. The growing mycelia were then cut in circualar shape with 
a $1 \mathrm{~cm}$ diameter. Furthermore, pathogenic bacteria were cultured in MHA media for antagonistic testing. Test bacteria used in this study were $P$. aeruginosa, $S$. aureus, $K$. pneumoniae, E. coli and B. cereus which are MDR strains. The test bacteria were obtained from the laboratory of Diponegoro National Hospital (RSND - Rumah Sakit Nasional Diponegoro) and collections belonging to the authors' peer group in the Integrated Laboratory of Diponegoro University, Semarang. Preparation of test bacteria used a 24-hour-old bacterial suspension with an equivalent size of $1.5 \times 10^{8} \mathrm{CFU} / \mathrm{ml}$ which were inoculated using the swab method. Fungal mycelium pieces were attached to the test bacterial culture and then the petri dish was closed and incubated for $24-48$ hours at $37{ }^{\circ} \mathrm{C}$ temperature. Antibacterial activity was demonstrated by the presence of inhibitory zones around the plug of fungal association.

\section{Fungal Cultivation}

Isolate subculture was carried out using MEA media. The mycelia after growing were taken using an ose needle in the form of a small circle with a $2 \mathrm{~mm}$ diameter. Mycelia cuts were inoculated in a new MEA (standard) and some modified media (solid, $20 \mathrm{ml} /$ petri dish), the $\mathrm{pH}$ was approaching neutral (approximately 5.60-6.50), and the salinity was $50-60 \%$. Furthermore, it was incubated for 6,7,8,9 days (dark and static 24hour conditions) at $27^{\circ} \mathrm{C}$ temperature. The media used were the standard MEA media, while modified media were from fish broth (M1, M2) and cassava infusion water (M3, M4). The followings are the process of making the media. MEA was made by dissolving $48 \mathrm{~g}$ of media in $1 \mathrm{~L}$ of sterile sea water (composition : malt extract $30 \mathrm{~g}$, peptone $3 \mathrm{~g}$, agar $15 \mathrm{~g}$ ) (Merck's protocol). Ml was made by boiling $100 \mathrm{~g}$ of thin slices of fish meat (Rastrelliger sp.) in $1 \mathrm{~L}$ of sea water for 30 minutes and then filtered. After that, the filtrate was added with $20 \mathrm{~g}$ of fructose and $15 \mathrm{~g}$ of agar (volume of the total solution $=1$ L). M2 is made as to the method for M1, but the filtrate was added with $20 \mathrm{~g}$ of glucose and $15 \mathrm{~g}$ of agar. M3 was made by boiling $100 \mathrm{~g}$ of thin cassava slices for 30 minutes in $1 \mathrm{~L}$ of sea water and then filtered. The filtrate was added with $15 \mathrm{~g}$ of agar (volume of the total solution $=1 \mathrm{~L}$ ). $\mathrm{M} 4$ was made as to the method done for M3 and the filtrate was added with 3 $\mathrm{g}$ of peptone and $15 \mathrm{~g}$ of agar.

\section{Extraction and Profiling of Secondary Metabolites}

Culture media and the mycelia, after being harvested, were macerated with methanol (1: $1 \mathrm{v} / \mathrm{v})$. Then, they were partitioned using distilled water (aquadest) and ethyl acetate $(1: 1 \mathrm{v} / \mathrm{v})$. After partition,

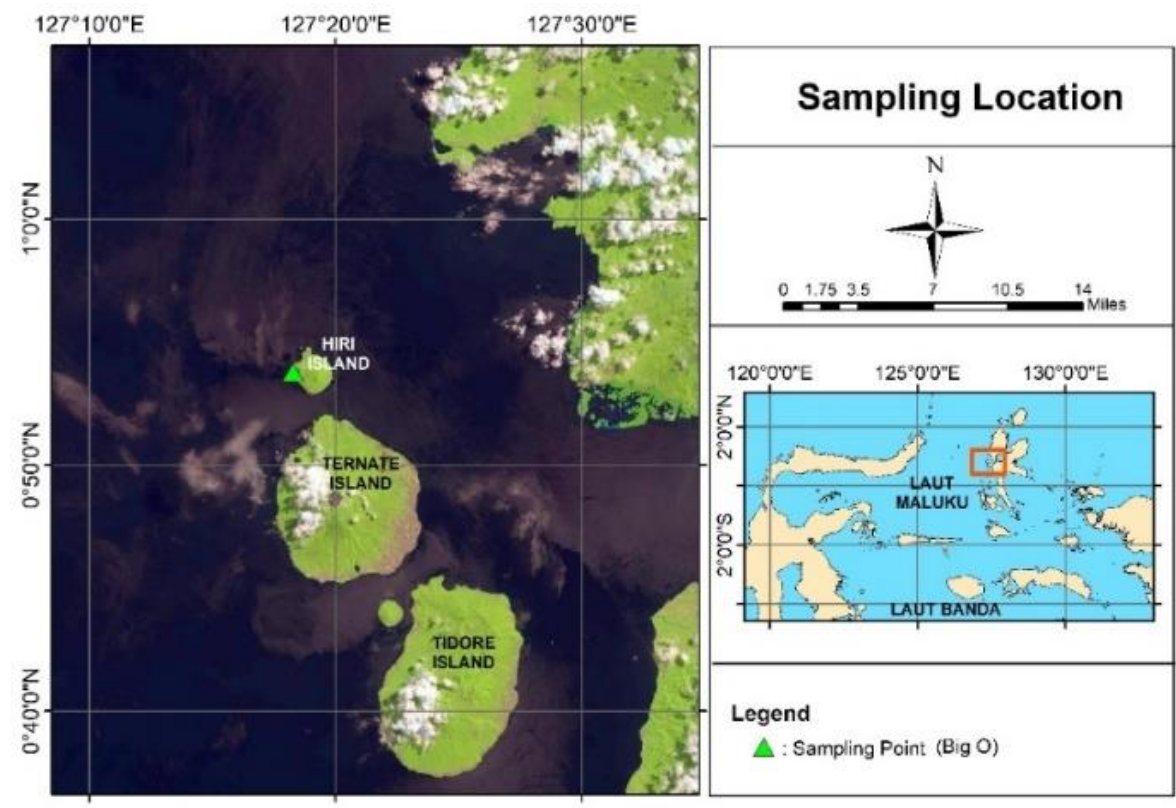

Figure1. Sampling Location of Hiri Island Waters 
each solvent was evaporated using rotavapour to obtain ethyl acetate (EEs) and methanol extracts (MEs). Extract profiling used the TLC method and followed by detection of compound groups based on spot reactions to $2 \%$ vanillin- $\mathrm{H}_{2} \mathrm{SO}_{4}$ (Harborne, 1973) and $0,25 \%$ ninhydrin reagent (Sen et al., 2012). The plates were heated at $110^{\circ} \mathrm{C}$ for $2-3$ minutes to emphasize spot sightings.

\section{Antimicrobial Activity}

The antibacterial bioassay was carried out by determining the diameter of the inhibitory zone using disc diffusion (antibacterial agar disc diffusion assay). It was conducted based on the method used by Trianto et al. (2017). Each extract in methanol solvent was tested against pathogenic bacteria using a $6 \mathrm{~mm}$ diameter Oxoid disc with $500 \mu \mathrm{g} / \mathrm{disc}$ concentration. The positive control was treated using chloramphenicol (Oxoid, $30 \mu \mathrm{g}$ ). Moreover, test bacteria were cultivated using Mueller Hinton Agar (MHA) media with (equivalent to) $1,5 \times 10^{8} \mathrm{CFU} / \mathrm{ml}$ initial density (REMEL MCFarland Equivalence), and the bioassay was tested after the bacteria aged 24-hour-old. Inhibition zones were measured after a 24-hour incubation period at $37^{\circ} \mathrm{C}$ temperature.

\section{RESULT AND DISCUSSION}

The fungus isolate with code TE-BO-09.1 which was able to inhibit 3 bacteria, i.e.: $K$. pneumoniae, B subtilis, and $S$. aureus, but unable to inhibit $E$. coli and $P$. aeruginosa (as described in Table 1). E. coli and $P$. aeruginosa bacteria were included in gramnegative bacteria which are known to be resistant to various antibiotics. This condition is supported by the ability of $E$. coli to produce extended -spectrum $\beta$-Lactamases enzymes (Extended Spectrum $\beta$-Lactamases/ESBL) which can degrade certain antibiotics ( $\beta$ lactam class) ((Farhat et al., 2009 ; Bimanand et al., 2017)) and can form capsules (Khan et al., 2015), while $P$. aeruginosa can form biofilms (Alhazmi, 2015). Based on Podschun \& Ullmann (1998) and Khan et al. (2015), the common triggers of malignancy from these gram-negative bacteria are the presence of endotoxin (toxin which is an integral part of cell walls of gram-negative bacteria) and adhesin (extracellular matrix and plasma protein deposits used to attach to biomaterials).

Morphological characteristics of fungus TE-BO-09.1 macroscopically and microscopically are described in Figure 3. Colonies produced by MEA cultivation had a greenish-yellow color, and when the petri dish was reversed, they looked yellowish. The conidiophore was long and the tip was round bulge and formed vesicles. The vesicles were surrounded by metula with uni- and biseriates of phialides. Besides, the tips of which were attached with many rounded form conidia. Referring to the results of previous studies, the fungal isolate used in this study was Aspergillus flavus (Zulkifli and Zakaria, 2017; Makhlouf et al., 2019). This assumption was consistent with its molecular identification.

All fungus Aspergillus flavus cultivated using modified media produced greater ethylacetate extract (EE) weight than they were in the control media (MEA). The highest extract weight was achieved by the use of $\mathrm{M} 4$, i.e. $38.67 \mathrm{mg} \mathrm{EE} / 20 \mathrm{ml}$ media with 9-daycultivation time, while MEA only produced $11.50 \mathrm{mg}$ on 7-day-cultivation. It also occurred in methanol extract (ME), except M4 which experienced the opposite thing. M1 media produced the highest extract as much as $245.00 \mathrm{mg} \mathrm{ME} / 20 \mathrm{ml}$ media with 7-daycultivation time, while the MEA produced $156.67 \mathrm{mg}$ at 8 -day-cultivation. Each fungal growth media produced the highest secondary metabolites at different cultivation times. This is consistent with the study conducted by Gliseida et al. (2013), Arumugam et al. (2014), and Sibero et al.

Table 1. Antagonistic Test of Fungus TE-BO-09.1 against MDR Pathogen Bacteria

\begin{tabular}{cccccc}
\hline \multirow{2}{*}{ Isolate } & \multicolumn{5}{c}{ Formation of the inhibition zones } \\
\cline { 2 - 6 } & E. coli & K. pneumoniae & B. subtilis & S. aureus & P. aeruginosa \\
\hline TE-BO-09.1 & - & + & + & + & - \\
\hline
\end{tabular}

$(+)$ presence of inhibition zone; (-) absence of inhibition zone 


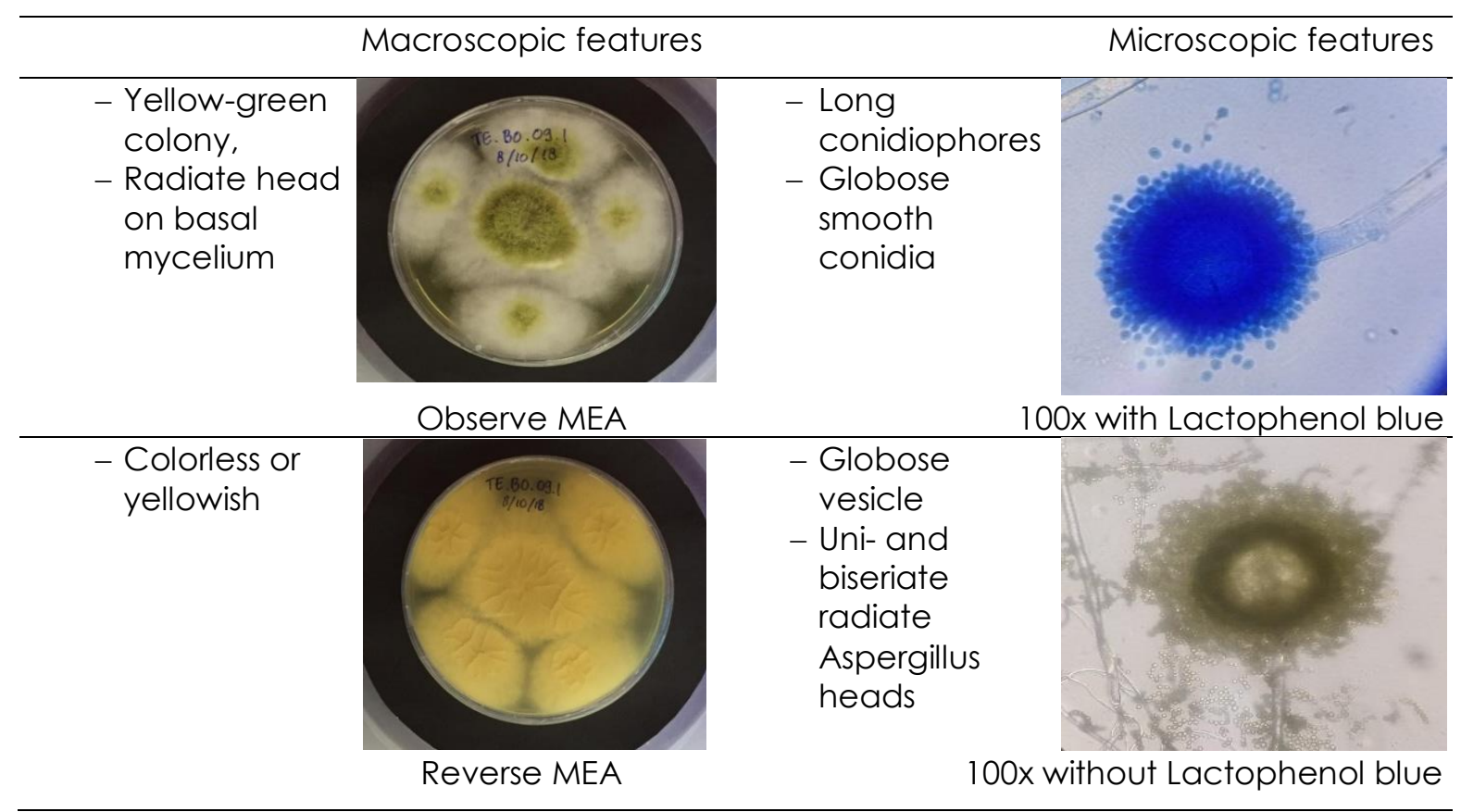

Figure 2. Morphological Characteristics of Fungus TE-BO-09.1 using MEA

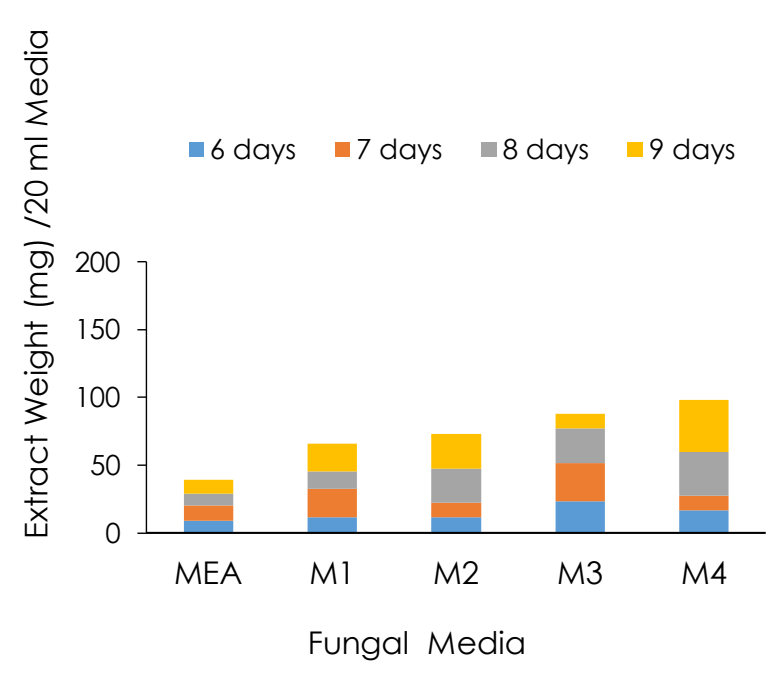

(a)

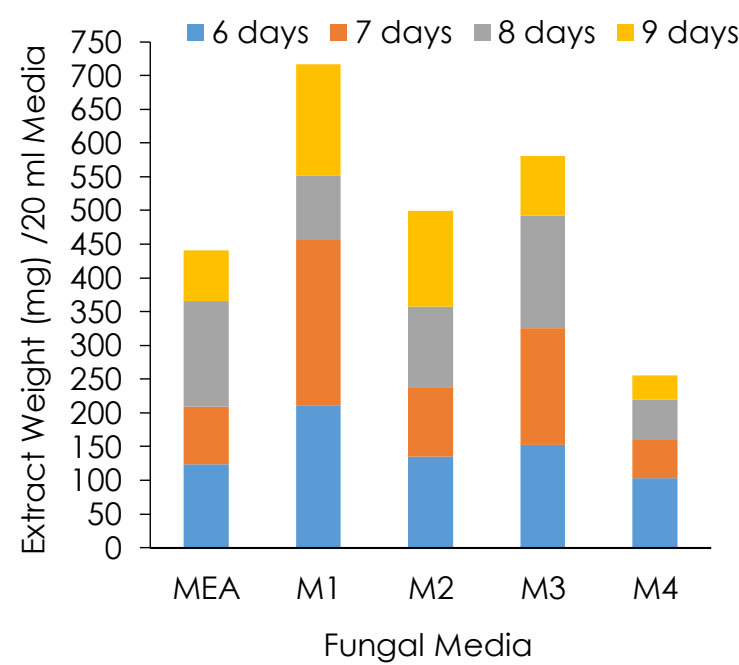

(b)

Figure 3. Weight of Fungus Aspergillus flavus Extracts at Different Cultivation Times (6-9 days), (a) Ethyl Acetate Extracts, (b) Methanol Extracts (Note : Standard = MEA; M1 = Fish Broth + Fructose; M2 = Fish Broth + Glucose; M3 = Cassava Infusion; M4 = Cassava Infusion + Peptone)

(2018) which stated that the production of secondary metabolites will increase as entering the stationary phase, and begins to occur on day 6 through 9 after cultivation.

Cultivation using MEA produced secondary metabolites that were naturally antibacterial through antagonistic testing (agar plug method). Nevertheless, it resulted in negative in testing antimicrobial activity $(500 \mu \mathrm{g} / \mathrm{disc})$. This result was probably due to its weak antibacterial characteristic, thus its active concentration was above $500 \mathrm{\mu g} /$ disc. Antibacterial bioassays of each extract are described in Table 2 showing the strongest $\mathrm{EE}$ from $M 2$ as the result of 9 days cultivation. 
Table 2. Inhibition Zones of The Aspergillus flavus Extracts at $500 \mu \mathrm{g} /$ disc concentration

\begin{tabular}{|c|c|c|c|}
\hline \multirow[t]{2}{*}{ Extract/ Cultivation Time (days) } & \multicolumn{3}{|c|}{ Diameter of Inhibition Zone (in mm including the disc) } \\
\hline & K. pneumoniae & S. aureus & B. subtilis \\
\hline & \multicolumn{3}{|c|}{ MEA } \\
\hline \multicolumn{4}{|l|}{ Ethyl Acetate: } \\
\hline 6 & $0.00 \pm 0.00$ & $0.00 \pm 0.00$ & $0.00 \pm 0.00$ \\
\hline 7 & $0.00 \pm 0.00$ & $0.00 \pm 0.00$ & $0.00 \pm 0.00$ \\
\hline 8 & $0.00 \pm 0.00$ & $0.00 \pm 0.00$ & $0.00 \pm 0.00$ \\
\hline 9 & $0.00 \pm 0.00$ & $0.00 \pm 0.00$ & $0.00 \pm 0.00$ \\
\hline \multicolumn{4}{|l|}{ Methanol : } \\
\hline 6 & $0.00 \pm 0.00$ & $0.00 \pm 0.00$ & $0.00 \pm 0.00$ \\
\hline 7 & $0.00 \pm 0.00$ & $0.00 \pm 0.00$ & $0.00 \pm 0.00$ \\
\hline 8 & $0.00 \pm 0.00$ & $0.00 \pm 0.00$ & $0.00 \pm 0.00$ \\
\hline 9 & $0.00 \pm 0.00$ & $0.00 \pm 0.00$ & $0.00 \pm 0.00$ \\
\hline \multicolumn{4}{|c|}{ Ml } \\
\hline \multicolumn{4}{|l|}{ Ethyl Acetate: } \\
\hline 6 & $0.00 \pm 0.00$ & $0.00 \pm 0.00$ & $0.00 \pm 0.00$ \\
\hline 7 & $0.00 \pm 0.00$ & $0.00 \pm 0.00$ & $0.00 \pm 0.00$ \\
\hline 8 & $0.00 \pm 0.00$ & $0.00 \pm 0.00$ & $0.00 \pm 0.00$ \\
\hline 9 & $0.00 \pm 0.00$ & $0.00 \pm 0.00$ & $0.00 \pm 0.00$ \\
\hline \multicolumn{4}{|l|}{ Methanol: } \\
\hline 6 & $0.00 \pm 0.00$ & $0.00 \pm 0.00$ & $7.47 \pm 0.25$ \\
\hline 7 & $0.00 \pm 0.00$ & $8.80 \pm 0.16$ & $7.47 \pm 0.26$ \\
\hline 8 & $0.00 \pm 0.00$ & $7.52 \pm 0.09$ & $7.30 \pm 0.19$ \\
\hline 9 & $0.00 \pm 0.00$ & $8.83 \pm 0.27$ & $7.92 \pm 0.28$ \\
\hline \multicolumn{4}{|c|}{ M2 } \\
\hline \multicolumn{4}{|l|}{ Ethyl Acetate: } \\
\hline 6 & $0.00 \pm 0.00$ & $0.00 \pm 0.00$ & $0.00 \pm 0.00$ \\
\hline 7 & $0.00 \pm 0.00$ & $0.00 \pm 0.00$ & $0.00 \pm 0.00$ \\
\hline 8 & $0.00 \pm 0.00$ & $0.00 \pm 0.00$ & $0.00 \pm 0.00$ \\
\hline 9 & $0.00 \pm 0.00$ & $10.32 \pm 0.01$ & $0.00 \pm 0.00$ \\
\hline \multicolumn{4}{|l|}{ Methanol: } \\
\hline 6 & $0.00 \pm 0.00$ & $8.04 \pm 0.50$ & $0.00 \pm 0.00$ \\
\hline 7 & $0.00 \pm 0.00$ & $8.52 \pm 0.19$ & $0.00 \pm 0.00$ \\
\hline 8 & $0.00 \pm 0.00$ & $8.83 \pm 0.50$ & $0.00 \pm 0.00$ \\
\hline 9 & $0.00 \pm 0.00$ & $9.43 \pm 0.00$ & $0.00 \pm 0.00$ \\
\hline \multicolumn{4}{|c|}{ M3 } \\
\hline \multicolumn{4}{|l|}{ Ethyl Acetate: } \\
\hline 6 & $0.00 \pm 0.00$ & $9.32 \pm 0.00$ & $0.00 \pm 0.00$ \\
\hline 7 & $0.00 \pm 0.00$ & $9.81 \pm 0.00$ & $0.00 \pm 0.00$ \\
\hline 8 & $0.00 \pm 0.00$ & $0.00 \pm 0.00$ & $0.00 \pm 0.00$ \\
\hline 9 & $0.00 \pm 0.00$ & $0.00 \pm 0.00$ & $0.00 \pm 0.00$ \\
\hline \multicolumn{4}{|l|}{ Methanol: } \\
\hline 6 & $7.84 \pm 0.42$ & $0.00 \pm 0.00$ & $8.05 \pm 0.48$ \\
\hline 7 & $7.65 \pm 0.00$ & $0.00 \pm 0.00$ & $7.31 \pm 0.15$ \\
\hline 8 & $7.53 \pm 0.42$ & $0.00 \pm 0.00$ & $7.39 \pm 0.07$ \\
\hline 9 & $7.58 \pm 0.33$ & $0.00 \pm 0.00$ & $7.14 \pm 0.45$ \\
\hline \multicolumn{4}{|c|}{ M4 } \\
\hline \multicolumn{4}{|l|}{ Ethyl Acetate: } \\
\hline 6 & $0.00 \pm 0.00$ & $0.00 \pm 0.00$ & $0.00 \pm 0.00$ \\
\hline 7 & $0.00 \pm 0.00$ & $0.00 \pm 0.00$ & $0.00 \pm 0.00$ \\
\hline 8 & $0.00 \pm 0.00$ & $0.00 \pm 0.00$ & $0.00 \pm 0.00$ \\
\hline 9 & $0.00 \pm 0.00$ & $0.00 \pm 0.00$ & $0.00 \pm 0.00$ \\
\hline \multicolumn{4}{|l|}{ Methanol: } \\
\hline 6 & $10.05 \pm 0.71$ & $0.00 \pm 0.00$ & $7.65 \pm 0.16$ \\
\hline 7 & $9.50 \pm 0.00$ & $0.00 \pm 0.00$ & $7.49 \pm 0.13$ \\
\hline 8 & $8.82 \pm 1.20$ & $7.98 \pm 0.41$ & $7.77 \pm 0.85$ \\
\hline 9 & $0.00 \pm 0.00$ & $7.42 \pm 0.00$ & $7.67 \pm 0.55$ \\
\hline Chloramphenicol (30 $\mathrm{gg} /$ disc) & $29.70 \pm 1.32$ & $31.37 \pm 2.05$ & $24.43 \pm 0.93$ \\
\hline
\end{tabular}


It was able to produce a $10.32 \mathrm{~mm}$ inhibition zones against $S$. aureus. The largest inhibition zone of ME was achieved when fungi association was cultivated for 6 days with M4, in which it was able to produce $10.05 \mathrm{~mm}$ diameter inhibition zone against $K$. pneumoniae. Based on the graph in Figure 2, 9-day-cultivation time (M2; EE) and 6-daycultivation time (M4; ME) were the periods when each media reached the highest extract weight.

The results of EEs (from all media) visualization using KLT with mobile phase $n$ hexane: ethylacetate (9: 1) produced several spots which positively reacted to $366 \mathrm{~nm}$ UV ( $\mathrm{Rf} 0.44,0.52,0.70$ ) and $2 \%$ vanillin- $\mathrm{H} 2 \mathrm{SO} 4$ reagent (Rf 0.78). Fluorescent blue compounds, when exposed to UV, are considered to be a group of organic compounds that possess double bonds (diene/polyene or conjugation) (Mohammed, 2018). Compounds which produce certain colored spots (varying colors) with vanillin reagents show the presence of alcohol and carbonyl functional groups (ketones, aldehydes). These compounds are included in terpenoid family, steroids, flavonoids, fatty acids/essential oils, phenolics, high molecular weight alcohols, and UV absorbing compounds. Vanillin reagents are sensitive to steroids (Harborne, 1973; Jork, 1990). Besides, the compounds which react positively to UV and vanillin are assumed to be in steroids or terpenoids categories since the results of their visualization are similar to the study done by Widyaningsih et al. (2018).

The results of MEs (from all media) visualization with mobile phase ethyl acetate: methanol: distilled water/aquadest (2: 2: 1) produced several spots which positively reacted to $366 \mathrm{~nm}$ UV ( $R f$ 0.71, 0.88), 2\% vanillin- $\mathrm{H} 2 \mathrm{SO} 4$ reagent (Rf 0.39 ) and $0.25 \%$ ninhydrin (0.48). Harborne (1973) stated that a positive reaction with ninhydrin reagent indicates that the substance is a compound containing nitrogen (amine, peptide, or alkaloid). The results of the research conducted by Retnowati et al. (2018) found that compounds of $\beta$-lactam and alkaloid groups produce purple spots when sprayed with ninhydrin. Moreover, polar compounds contained in ME may be included in phenolic groups, terpenoid derivatives, and alkaloids or other compounds containing nitrogen such as amines and peptides.

\section{CONCLUSION}

This Aspergillus flavus is provably able to inhibit 3 bacteria, i.e. K. pneumoniae, B subtilis, and $S$. aureus, but not able to inhibit $E$. coli and $P$. aeruginosa. Fungus cultivation used standard MEA and modified media from fish broth and cassava infusion water which produced secondary metabolites with varying quantities and antimicrobial activities. The inhibition zone of the produced extract with $500 \mathrm{\mu g} /$ disc concentration ranged from 7.14 to $10.32 \mathrm{~mm}$. The strongest potential was shown by ethyl acetate extract from fungus cultured with fish broth M2 ( 9 days cultivation) which were able to produce $10.32 \mathrm{~mm}$ inhibition zone against $S$. aureus and methanol extracts from fungus cultured with cassava infusion water M4 16 days cultivation), producing $10.05 \mathrm{~mm}$ inhibition zone against $K$. pneumoniae.

\section{ACKNOWLEDGMENT}

This research is a part of a series of doctoral studies. The funding of the study is from Grant Program of the Faculty of Fisheries and Marine Sciences, Diponegoro University, fiscal year 2019 with contract number : 35/UN 7.5.10/PP/2019.

\section{REFERENCES}

Ahmad, A. 2015. Nosocomial Infections \& Their Control Strategies. Asian Pacific Journal of Tropical Biomedicine, 5(7):505509.

Almasaudi, S.B. 2015. Acinetobacter spp. as Nosocomial Pathogens: Epidemiology \& Resistance Features. Saudi Journal of Biological, 2016:1-5. DOI: 10.1016/j.sjbs.20 1602.009.

Bimanand, L., Sadeghifard, N., Jalilian, F.A., Hossainzadegan, H., Darbidi, S.M., Hemahian, A., Ghafourian, S., \& Pakzad, I. 2017. Microbiology, Clinical, Medical Sciences, Medical Sciences, \& Medical Sciences. J Bas Res Med Sci., 4(1):17-21.

Bereket, W., Hemalatha, K., Getenet, B., Wondwossen, T., Solomon, A., Zeynudin, 
A., \& Kannan, S. 2012. Update on Bacterial Nosocomial Infections. European Review for Medical \& Pharmacological Sciences, 16:1039-1044. Bologa, C.G., Ursu,O., Oprea, T.I., Melançon, C.E., \& Tegos, G.P. 2013. Emerging Trends in the Discovery of Natural Product Antibacterials. Current Opinion in Pharmacology, 13(5):678-687.

Bouguenoun, W., Bentorki, A.A., Bouguenoun, I., \& Merad, T. 2016. Nosocomial Infection Caused by Multidrug Resistant Enterobacteriaceae \& Their Spread in Inanimate Surfaces in East-Algerian Hospitals. African Journal of Microbiology Research, 10(32): 12861291. DOI: 10.5897/AJMR2016.8167.

Farhat, U., Malik, S.A., \& Jawad, A. 2009. Antibiotic Susceptibility Pattern \& ESBL Prevalence in Nosocomial Escherichia coli from Urinary Tract Infections in Pakistan. African Journal of Biotechnology, 8:3921-3926.

Handayani, D., Ahdinur, R.F., \& Rustini, R. 2015. Antimicrobial Activity of Endophytic Fungi from Marine Sponge Haliclona fascigera. Journal of Applied Pharmaceutical Science, 5(10):154-156.

Harborne, J.B. 1973. Phytochemical Methods: A Guide to Modern Techniques of Plant Analysis. Chapman and Hall, New York, 278 p.

Jork, H., Funk, W., Fisher, W., \& Wimmer, H. 1990. Thin-Layer Chromatography: Reagents and Detection Methods, Vol.1: Physical and Chemical Detection Methods. VCH Weinham, Germany.

Kemenkes RI. 2011. Pedoman Umum Penggunaan Antibiotik. Direktorat Bina Kefarmasian \& Alat Kesehatan, Jakarta, 85 hal.

Kemenkes RI. 2015. Permenkes RI Nomor 8 Tahun 2015 : Program Pengendalian Resistensi Antimikroba di Rumah Sakit. Kemenkes Rl, Jakarta, 31 hal.

Krzowska-Firych, J., Sukhadia, T., \& Al-mosawi, L.K. 2014. Hospital-Acquired Infections Caused by Antibiotic Resistant Bacteria Zakażenia Szpitalne Wywołane Przez Lekooporne Bakterie. Postępy Nauk Medycznych, 11:783-86.

Makhlouf, J., Carvajal-Campos, A., Querin, A., Tadrist, S., Puel, O., Lorber, S., Oswald, I.P., Hamze, M., Jean-Denis Bailly, \& Bailly, S.
2019. Morphologic, Molecular and Metabolic Characterization of Aspergillus Section Flavi in Spices Marketed in Lebanon. Scientific Reports, 9(1):1-11.

Maurya, S. P., Prakash, P.Y., \& Bairy, I. 2011. A Simplified Touch Tape Preparation from Tube Cultures for Microscopic Examination of Filamentous Fungi." Journal of Microbiological Methods, 86(1): 128-29. DOI : 10.1016/j.mimet.2011. 04.015 .

Mohammed, A.M. 2018. UV-Visible Spectrophotometric Method and Validation of Organic Compounds. European Journal of Engineering Research and Science, 3(3): 8-11.

Nielsen, J.C. \& Nielsen, J. 2017. Development of Fungal Cell Factories for the Production of Secondary Metabolites: Linking Genomics \& Metabolism. Synthetic \& Systems Biotechnology, 2(1):5-12. DOI : 10.1016/j.synbio.2017.02. 002.

Özkaya, F.C., Ebrahima, W., El-Neketic, M., Tanrıkulb, T.T., Kalschevera, R., Müllerd, W.E.G., Guoe, Z., Zove, K., Liva, Z., \& Prokscha, P. 2018. Induction of $\mathrm{New}$ Metabolites from Sponge-Associated Fungus Aspergillus carneus by OSMAC Approach. Fitoterapia, 131:9-14.

Podschun, R. \& Ullmann, U. 1998. Klebsiella spp. as Nosocomial Pathogens: Epidemiology, Taxonomy, Typing Methods, and Pathogenicity Factors Klebsiella spp. as Nosocomial Pathogens: Epidemiology, Taxonomy, Typing Methods and Pathogenicity Factors. Journal of Clinical Microbiology, 11(4): 589-603.

Retnowati, Y., Moeljopawiro, S., Djohan, Tj. S., \& Soetarto, E. S. 2018. Antimicrobial Activities of Actinomycete Isolates from Rhizospheric Soils in Different Mangrove Forests of Torosiaje, Gorontalo, Indonesia. Biodiversitas, 19(6):2196-2203

Romano, S., Jackson, S.A., Patry, S., \& Dobson, A.D.W. 2018. Extending the 'one Strain Many Compounds' (OSMAC) Principle to Marine Microorganisms. Marine Drugs, 16(7):1-29

Sen, S., Sarkar, S., Kundu, P., \& Laskar, S. 2012. Separation of Amino Acids Based on ThinLayer Chromatography by a Novel 
Quinazoline Based Anti-Microbial Agent. American Journal of Analytical Chemistry, 3(9) : 669-674. DOI : 10.4236/ ajac.2012.39088.

Sibero, M. T., Triningsih, D.W., Radjasa, O.K., Sabdono, A., \& Trianto, A. 2017. Evaluation of Antimicrobial Activity and Identification of Yellow Pigmented Marine Sponge-Associated Fungi from Teluk Awur, Jepara, Central Java. Indonesian Journal of Biotechnology, $21(1): 1-11$

Sihombing, R., Bara, A., \& Fitje, L. 2017. Skrining Aktivitas Antibiotik Jamur Simbion pada Spons di Perairan Malalayan.Jurnal Pesisir dan Laut Tropis, 1 (1):1-8.

Spangenberg, B., Poole, C.F., \& Weins, C. 2011. Quantitative Thin-Layer Chromatography : A Practical Survey. Springer, Berlin, 387p.

Trianto, A., Widyaningsih, S., Radjasa, O.K., \& Pribadi, R. 2017. Symbiotic Fungus of Marine Sponge Axinella sp. Producing Antibacterial Agent Symbiotic Fungus of Marine Sponge Axinella sp. Producing Antibacterial Agent. IOP Conf. Series: Earth and Environmental Science, 55: 012005.
Trianto, A., Sedjati, S., Radjasa, O.K., Sabdono, A., Muchlisisn, S.I., Radjasa, S.K., Afriyanto, R., Bahry, M.S., Crew, P., \& McCauley. E. 2020. Exploration of The Sponge-Assosiated Fungi from Ternate Water, Indonesia. INPRESS.

Widyaningsih, S., Trianto, A., Radjasa, O,K., \& Wittriansyah, K. 2018. Antibacterial Activity Symbiotic Fungi of Marine Sponge Axinella sp., Aspergillus Sydowii on Four Growth Medium. IOP Conference Series: Earth and Environmental Science, 116(1): 0-8.

Wittriansyah, K., Trianto, A., Widyaningsih, S., Radjasa, O.K., \& Pribadi, R. 2016. Screening of Antibacterial MDR Derived from Sponge Associated Fungus of Riung Water, Nusa Tenggara Timur.Journal of Marine Science, 21 (4): 197-202.

Zhou, S., Wang, M., Feng, Q ., Lin, Y., \& Zhao, H. 2016. A Study on Biological Activity of Marine Fungi from Different Habitats in Coastal Regions. Springer Plus, 5: 4-11.

Zulkifli, N. A., \& Zakaria, L. 2017. Morphological and Molecular Diversity of Aspergillus From Corn Grain Used as Livestock Feed. HAYATI Journal of Biosciences, 24(1): 2634. 